\title{
SISTEM PENDUKUNG KEPUTUSAN PENERIMA BEASISWA TIDAK MAMPU MENGGUNAKAN METODE MOORA
}

\author{
Yusni Amaliah, Suprianto \\ Program Studi Sistem Informasi, STMIK PPKIA Tarakanita Rahmawati \\ Jl. Yos Sudarso, RT. 08 \\ lily@ppkia.ac.id, suprieppkia.ac.id
}

\begin{abstract}
The process of distributing scholarship funds often occurs education of in the world, one of which is the lack of targets in the admission process. There are several criteria that must be met by school students in determining scholarship recipients, including the condition of the house to live in, water and electricity facilities, parents' income and the vehicle used to go to school. Therefore, an effective method is needed in determining which students are eligible to receive underprivileged scholarships, namely Multi Objective Optimization on the Basis of Ratio. This method has criteria and sub criteria as well as a weighted value that is given based on the importance of these criteria. Based on the calculation results, 6 data were obtained as scholarship recipients with a value range between $25 \mathrm{~s}$ / d 27 which is the highest value of each criteria.
\end{abstract}

Keywords - Decision Support System, scholarship, Moora.

\begin{abstract}
Abstrak - Proses penyaluran dana beasiswa masih sering terjadi dalam dunia pendidikan salah satunya yaitu kurang tepat sasaran dalam proses penerimaannya. Terdapat beberapa kriteria yang harus dipenuhi oleh siswa sekolah dalam menentukan penerima beasiswa, antara lain keadaan rumah tempat tinggal, fasilitas air dan listrik, penghasilan orang tua serta kendaraan yang digunakan untuk berangkat ke sekolah. Tujuan penelitian ini adalah membantu Dinas Sosial dalam menentukan siswa yang layak menerima beasiswa tidak mampu. Dalam proses pengambilan keputusan tersebut digunakan metode Multi Objective Optimization on the Basis of Ratio. Berdasarkan hasil perhitungan, maka diperoleh 6 (enam) data siswa sebagai penerima beasiswa dengan range nilai antara 25 s/d 27 yang merupakan nilai tertinggi dari setiap kriteria.
\end{abstract}

Kata Kunci - Sistem Pendukung Keputusan, Beasiswa, Moora.

\section{PENDAHULUAN}

Permasalahan yang terjadi di zaman sekarang ini dapat dengan mudah dipecahkan dengan teknologi komputer, [13] salah satunya pada bidang pendidikan yaitu seleksi beasiswa. Beasiswa adalah bantuan yang diberikan oleh pihak tertentu yang digunakan untuk biaya pendidikan. Beasiswa terdiri dari beberapa jenis antara lain beasiswa prestasi dan beasiswa tidak mampu. Dalam pemberian beasiswa terdapat beberapa kriteria atau persyaratan yang harus dipenuhi oleh siswa yang akan mengajukan bantuan antara lain fotocopy kartu pelajar, domisili tempat tinggal, surat ketarangan tidak mampu dari RT setempat, serta beberapa dokumen penunjang lainnya. Adapun kendala yang sering dihadapi oleh Dinas Sosial pada Pemerintah Kota Tarakan dalam memberikan bantuan adalah proses seleksi dengan jumlah siswa yang mengajukan sangat banyak dan berdasarkan dari persyaratan dan kelengkapan dokumen harus dilakukan pengecekan satu persatu serta dihitung secara manual. Dari masalah tersebut, penelitian tentang sistem pendukung keputusan (SPK) berdasarkan kriteria yang mendukung pengambilan keputusan sehingga dapat membantu dalam mempercepat penentuan penerima beasiswa dan tentunya tepat sasaran.
Pada penelitian yang dilakukan Syaiful $\mathrm{R}$ dkk, Metode moora digunakan utuk menentukan kelompok uang kuliah tunggal yang ditanggung oleh mahasiswa berdasarkan kemampuan ekonominya. Samuel manurung melakukan penelitian tentang pemilihan guru dan pegawai terbaik menggunakan metode moora untuk mengetahui akurasi nilai. Denita Pasaribu \& Rivalri K.H, meneliti bagaimana cara melakukan pemilihan bidan terbaik menggunakan metode moora sehingga mendapatkan bidan yang benar-benar bertanggung jawab.

Sistem pendukung keputusan yang dibuat menggunakan metode Moora. Metode tersebut dipilih karena memiliki suatu bentuk model system yang dapat memberikan hasil keputusan terbaik yang didasarkan pada kriteria dan bobot yang sudah dibuat oleh bagian pelaksana beasiswa yaitu Dinas Sosial pada Pemerintah Kota Tarakan. Metode ini juga merupakan sebuah metode yang mempunyai perhitungan kalkulasi yang sederhana dan juga memiliki nilai minimum [1]. Hasil dari sistem pendukung keputusan menggunakan metode Moora yaitu data penerima dana beasiswa tidak mampu.

\section{A. Sistem Pendukung Keputusan (SPK)}

SPK atau yang biasa disebut juga Decision Support System adalah merupakan sebuah system yang dapat digunakan untuk memecahkan 
permasalahan yang memiliki kemampuan dalam mengkomunikasikan masalah mulai dari yang terstruktur ataupun semi struktur. SPK memiliki tujuan dalam memberikan beberapa informasi, dan memiliki prediksi yang dapat mengarahkan kepada para pengguna informasi sehingga pengguna dapat mengambil keputusan dengan lebih efektif dan tepat sasaran.

Para pengguna dalam menggambil kebijakan dapat disebabkan oleh beberapa faktor yang tentu saja dapat mempengaruhi seorang dalam mengambil keputusan. Untuk itu perlu dilakukan identifikasi dari berbagai macam faktor penting dalam menimbang faktor tersebut dalam mengambil suatu keputusan. Dari permasalahan itu, pada penelitian ini penulis menerapkan sebuah metode pengambilan keputusan untuk penentuan beasiswa tidak mampu. Metode Moora sangat mudah dipahami dan diimplementasikan karena memiliki perhitungan sederhana. Metode Moora juga mempunyai sebuah teknik optimasi multi objective yang sangat cocok digunakan dalam menyelesaikan Bermacam-macam jenis pengambilan keputusan yang sulit diselesaikan [2][4][5].

\section{B. Konsep Dasar Sistem Pendukung Keputusan}

Awal mula konsep dasar spk diperkenalkan pertama kali oleh Scott Morton pada sekitar awal tahun 1970. Dalam hal ini Scott Morton memberikan pengertian SPK yaitu sebuah sistem yang mempunyai basis komputer secara interaktif, yang digunakan untuk membantu dalam mengambil keputusan. Sistem menggunakan beberapa macam data dan model yang digunakan dalam menyelesaikan permasalahan yang tidak terstruktur. System ini memiliki perancangan yang baik untuk mendukung semua tahap dalam membuat keputusan yang biasanya dilakukan dari tahap identifikasi permasalahan, menentukan data yang sesuai, menentukan berbagai macam pendekatan untuk digunakan dalam proses mendukung pemecahan masalah sampai pada pemilihan beberapa alternatif [2][6].

\section{Metode MOORA}

Pada tahun 2006 Metode Moora merupakan sebuah model sistem pendukung keputusan yang dikenalkan oleh Brauers dan Zavadskas. Metode ini banyak digunakan dalam rangka menyelesaikan banyak permasalahan misalnya di bidang manajerial, ekonomi dan dapat juga pada bidang konstruksi dengan cara perhitungan menggunakan rumus matematika untuk menghasilkan data yang tepat (Gadakh, 2011) [3][2][7].

\section{Penerapan Formula Metode MOORA}

Metode Moora memiliki beberapa tahapan dalam melakukan perhitungan yaitu

1. Masukkan nilai Kriteria

Memasukkan nilai kriteria yang terdapat dalam sebuah alternative yang kemudian nilai itu akan menjadi sebuah nilai keputusan untuk melakukan proses perhitungan selanjutnya.

2. Mengubah nilai kriteria ke matriks keputusan

Nilai matriks keputusan digunakan sebagai sebuah tolak ukur kinerja dari alternative I th pada sebuah atribut $J$ th. Sedangkan $M$ merupakan sebuah alternative dan $\mathrm{N}$ merupakan jumlah atribut. Sistem rasio kemudian dikembangkan sehingga setiap kinerja yang merupakan sebuah alternatif pada atribut di berikan perbandingan dengan nilai penyebut digunakan sebagai wakil untuk semua alternatif dari atribut. Di bawah ini adalah perubahan dari nilai kriteria yang menjadi sebuah nilai matriks keputusan menggunakan persamaan $1:$ [2][4]

$$
\mathbf{X}=\left|\begin{array}{lll}
X_{11} & X_{12} & X_{13} \\
X_{21} & X_{22} & X_{23} \\
X_{m 1} & X_{m 2} & X_{m n}
\end{array}\right|
$$

\section{E. Normalisasi.}

Pada Proses normalisasi digunakan untuk menyatukan dari setiap element matriks sehingga membuat nilai element pada matriks memiliki nilai yang sama. Normalisasi ini merupakan tahapan yang dilakukan dalam proses perhitungan metode Moora. Normalisasi ini dapat dihitung dengan persamaan 2 sebagai berikut : [2][5][8]

$$
X i j=\frac{X i j}{\sqrt{\sum_{j=1}^{m} X^{2} i j}}
$$

\section{Keterangan :}

$\mathrm{X}_{\mathrm{ij}} \quad$ : ukuran ke i dari alternatif untuk kriteria ke ${ }_{\mathrm{j}}$

m : total jumlah alternatif

n : jumlah kriteria

\section{F. Mengurangi nilai maximax dan minimax}

Dalam proses pengurangan nilai maximax dan minimax sebuah atribut lebih penting harus ditandai, ini dapat dilakukan dengan mengalikan nilai bobot yang sesuai (koefisien signifikasi) Atribut bobot yang ditimbang menggunakan perhitungan dengan persamaan 3: [2][4]

$$
Y i^{n}=\sum_{j=1}^{g}=W j X^{n} i j-\sum_{j=g+1}^{n} W_{j} X^{n} i j
$$

Keterangan :

Wj : bobot kriteria ke-j

\section{G. Penentuan Nilai Rangking dari Hasil Perhitungan}

Penentuan nilai $\mathrm{Y}_{\mathrm{i}}$ memiliki dua macam nilai yaitu nilai negatif dan positif, hal ini bergantung pada nilai total maksimal yaitu atribut yang bersifat menguntungkan dalam nilai matriks keputusan. Pilihan terakhir ditentukan dari nilai $Y_{i}$ [3]. Nilai alternatif terbaik dapat ditentukan dari nilai $\mathrm{Y}_{\mathrm{i}}$ tertinggi, yaitu dalam hal perangkingan ditentukan dari nilai yang paling tinggi, sedangkan nilai alternatif terburuk dinilai berdasarkan nilai yang terendah dari rangking 
yang telah dilakukan. Dari nilai tersebut kita dapat menentukan atau mengambil keputusan berdasarkan nilai yang telah dihitung dengan rumus metode Moora. Nilai rangking dalam pengambilan keputusan dapat disesuaikan dengan batasan masalah yang diteliti.

\section{METODE PENELITIAN}

Metode penelitian yang digunakan dalam penelitian ini dimulai dari menentukan atribut yang akan dinilai, dapat dilihat pada Gambar 1 yang merupakan skema alur perhitungan metode MOORA dalam menentukan penerima beasiswa tidak mampu.

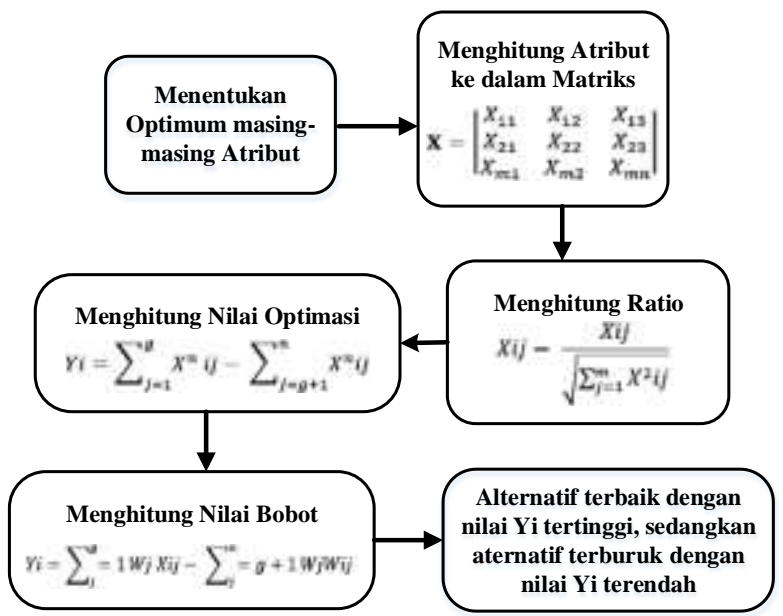

Gambar 1. Bagan Alir Metode Moora

Dari gambar 1 diatas, terdapat beberapa tahapan, antara lain :

\section{Menentukan Optimum Atribut}

Data yang digunakan dalam penelitian adalah data siswa penerima beasiswa yang telah mendaftar pada Dinas Sosial Kota Tarakan. Adapun kriteria yang digunakan dapat dilihat pada Tabel 1:

Tabel 1. Tabel Kriteria

\begin{tabular}{|c|c|c|}
\hline Kriteria & Sub Kriteria & Ket \\
\hline $\begin{array}{l}\text { Luas Lantai } \\
\text { Rumah }\end{array}$ & $\begin{array}{l}\text { a) }<=10 \mathrm{~m}^{2} \\
\text { b) }>10 \mathrm{~m}^{2} \&<=15 \mathrm{~m}^{2} \\
\text { c) }>=15 \mathrm{~m}^{2} \&<=25 \mathrm{~m}^{2}\end{array}$ & Max \\
\hline $\begin{array}{l}\text { Jenis Lantai } \\
\text { Rumah }\end{array}$ & \begin{tabular}{ll|} 
a) & Tanah \\
b) & Dirabat \\
c) & Semen / Ubin \\
\end{tabular} & Max \\
\hline $\begin{array}{l}\text { Jenis } \\
\text { Dinding } \\
\text { Rumah }\end{array}$ & $\begin{array}{l}\text { a) Bambu / rumbia / kayu murahan } \\
\text { b) Tembok tanpa plester } \\
\text { c) Tembok plester }\end{array}$ & Max \\
\hline $\begin{array}{l}\text { Jenis Atap } \\
\text { Rumah }\end{array}$ & $\begin{array}{l}\text { a) Rumbia / Bambu / Alang-alang } \\
\text { b) Seng / Asbes / Genteng tanpa } \\
\text { plafon } \\
\text { c) Seng / Asbes / Genteng dengan } \\
\text { plafon }\end{array}$ & Max \\
\hline WC & $\begin{array}{ll}\text { a) } & \text { Tidak mempunyai WC } \\
\text { b) } & \text { WC dinding batako / batu / bata } \\
\text { c) } & \text { WC dengan dinding plester } \\
\end{array}$ & Max \\
\hline Listrik & $\begin{array}{ll}\text { a) } & \text { Tidak punya listrik } \\
\text { b) } & \text { Punya dengan daya } 450 \text { watt }\end{array}$ & Max \\
\hline
\end{tabular}

\begin{tabular}{|l|ll|c|}
\hline & c) & Punya dengan daya 900 watt & \\
\hline Air & a) & Mata air / sungai & Max \\
& b) & Sumur / cubang & \\
& c) & PDAM & \\
\hline Sarana & a) & Jalan Kaki / Angkutan Umum & Max \\
Transportasi & b) & Sepeda & \\
& c) & Sepeda Motor / Antar Jemput & \\
\hline Penghasilan & a) & $<$ Rp. 500000 & Min \\
Orang Tua / & b) $>=$ Rp. 1000000 \& <= Rp. 1500000 & \\
bulan & c) $>$ Rp. $1500000 \&<=$ Rp. 2000000 & \\
\hline
\end{tabular}

Pada Tabel 1 terdapat 9 kriteria dan sub kriteria yang digunakan dalam sistem pengambilan keputusan. Nilai max berfungsi untuk penambahan nilai bobot pada saat perhitungan matriks, sedangkan nilai min berfungsi sebagai pengurangan nilai matriks dimana jumlah minimal adalah nilai tertinggi pada kriteria. Kemudian data tiap kriteria diberi nilai bobot sesuai jenis kriterianya, dapat dilihat pada Tabel 2 :

Tabel 2. Nilai bobot kriteria

\begin{tabular}{|l|c|c|}
\hline \multicolumn{1}{|c|}{ Kriteria } & $\begin{array}{c}\text { Sub } \\
\text { Kriteria }\end{array}$ & Ket \\
\hline Luas Lantai Rumah & 15 & Benefit \\
\hline Jenis Lantai Rumah & 15 & Benefit \\
\hline Jenis Dinding Rumah & 15 & Benefit \\
\hline Jenis Atap Rumah & 10 & Benefit \\
\hline WC & 15 & Benefit \\
\hline Listrik & 15 & Benefit \\
\hline Air & 15 & Benefit \\
\hline Sarana Transportasi & 10 & Benefit \\
\hline Penghasilan Orang Tua / bulan & 10 & Cost \\
\hline
\end{tabular}

Nilai optimasi merupakan hasil perhitungan dari bobot masing-masing kriteria yang telah ditentukan oleh dinas sosial. Tingkat kepentingan dari masingmasing kriteria menghasilkan nilai maksimal dan nilai minimal.

Setelah data kriteria diperoleh, selanjutnya menghitung data alternatif sesuai dengan kriteria yang dimiliki menggunakan metode MOORA. Hasil dari perhitungan akan menunjukkan nilai alternatif tertinggi sebagai penerima beasiswa.

\section{HASIL DAN PEMBAHASAN}

Bagian ini akan menjelaskan proses kerja metode MOORA serta cara perhitungan masing-masing kriteria untuk memperoleh data yang akan mendapatkan bantuan beasiswa tidak mampu. Berdasarkan rumus metode MOORA yang telah dijelaskan diatas.

Berdasarkan data sub kriteria yang terdiri lebih dari satu, maka nilai akan dicari rata-ratanya untuk menghasilkan nilai pada matriks keputusan menggunakan persamaan 2 .

$$
\text { Alternatif A1 : } \begin{aligned}
\mathrm{C} 1 & =(80+72+82) / 3=78 \\
\mathrm{C} 2 & =(81+81+81) / 3=81 \\
\mathrm{C} 3 & =(81+75+80) / 3=78,8 \\
\mathrm{C} 4 & =(85+80+81) / 3=82
\end{aligned}
$$




$$
\begin{aligned}
& \mathrm{C} 5=(80+71+60) / 3=70,3 \\
& \mathrm{C} 6=(85+82+85) / 3=84 \\
& \mathrm{C} 7=(50+81+85) / 3=72 \\
& \mathrm{C} 8=(70+85+80) / 3=78,3 \\
& \mathrm{C} 9=(65+60+65) / 3=63,3
\end{aligned}
$$

Nilai C1 diperoleh dari kriteria pertama yaitu Luas Lantai Rumah, dengan sub kriteria $<=10 \mathrm{~m}^{2}$ dengan nilai 80, diikuti dengan sub kriteria kedua dengan nilai 72 , dan sub kriteria ketiga dengan nilai 82. Nilai $\mathrm{C} 2$ sampai dengan $\mathrm{C} 9$ sama dengan nilai untuk tiap kriteria. Perhitungan untuk alternatif yang lain sama dengan proses perhitungan pada alternatif pada A1. Kriteria dan sub kriteria yang diberikan berdasarkan nilai bobot pada dinas sosial ditampilkan dalam Tabel 3 sebagai hasil perhitungan data uji metode MOORA.

Tabel 3. Matriks Keputusan

\begin{tabular}{|c|c|c|c|c|c|c|}
\hline Alternatif & C1 & C2 & ... & C7 & C8 & C9 \\
\hline A1 & 78.0 & 81.0 & & 72.0 & 78.3 & 63.3 \\
\hline A2 & 71.7 & 80.3 & & 61.7 & 71.7 & 60.0 \\
\hline A3 & 75.7 & 80.7 & & 61.7 & 65.0 & 65.0 \\
\hline A4 & 70.7 & 80.3 & & 66.7 & 71.7 & 61.7 \\
\hline A5 & 79.7 & 78.3 & & 61.7 & 71.7 & 68.3 \\
\hline A6 & 74.0 & 81.0 & & 79.0 & 76.7 & 80.0 \\
\hline A7 & 82.0 & 80.7 & & 63.3 & 72.0 & 70.0 \\
\hline A8 & 71.7 & 78.7 & & 60.0 & 71.7 & 68.3 \\
\hline A9 & 73.3 & 70.0 & & 58.0 & 71.7 & 71.7 \\
\hline A10 & 77.7 & 70.0 & & 60.7 & 73.3 & 78.3 \\
\hline A11 & 79.0 & 71.7 & & 68.0 & 75.0 & 61.7 \\
\hline A12 & 79.3 & 80.3 & & 70.0 & 75.0 & 71.7 \\
\hline A13 & 78.3 & 80.0 & & 72.0 & 75.0 & 71.7 \\
\hline A14 & 73.3 & 80.7 & & 81.3 & 73.3 & 68.3 \\
\hline A15 & 77.7 & 69.7 & & 72.3 & 65.0 & 71.7 \\
\hline A16 & 79.3 & 81.7 & & 73.3 & 68.3 & 75.0 \\
\hline$\sum$ & 305.6 & 311.7 & & 271.8 & 289.2 & 277.6 \\
\hline & & & & & & \\
\hline
\end{tabular}

Dari hasil perhitungan matriks keputusan pada tabel diatas kemudian dilakukan perhitungan normalisasi matriks dengan membagi hasil perhitungan dengan masing-masing nilai pada kriteria dengan menggunakan persamaan 1 .

$$
\begin{array}{r}
\text { Alternatif A1 : } 1=78 / 305,6=0,26 \\
\mathrm{C} 2=81 / 311,7=0,26 \\
\mathrm{C} 3=78,8 / 306,1=0,26 \\
\mathrm{C} 4=82 / 299,5=0,27 \\
\mathrm{C} 5=70,3 / 240=0,29 \\
\mathrm{C} 6=84 / 300,3=0,28 \\
\mathrm{C} 7=72 / 271,8=0,26 \\
\mathrm{C} 8=78,3 / 289,2=0,27 \\
\mathrm{C} 9=63,3 / 277,6=0,23
\end{array}
$$

Perhitungan untuk Alternatif A2 sampai dengan A16 sama dengan perhitungan A1. Hasil perhitungan ditampilkan pada tabel normalisasi matriks dilihat pada Tabel 4 dibawah ini.

Tabel 4. Normalisasi Matrik

\begin{tabular}{|l|c|c|c|c|c|c|}
\hline Alternatif & C1 & C2 & $\ldots$ & C7 & C8 & C9 \\
\hline
\end{tabular}

\begin{tabular}{|l|l|l|l|l|l|l|} 
A1 & 0.26 & 0.26 & $\ldots$ & 0.26 & 0.27 & 0.23 \\
\hline A2 & 0.23 & 0.26 & $\ldots$ & 0.23 & 0.25 & 0.22 \\
\hline A3 & 0.25 & 0.26 & $\ldots$ & 0.23 & 0.22 & 0.23 \\
\hline A4 & 0.23 & 0.26 & $\ldots$ & 0.25 & 0.25 & 0.22 \\
\hline A5 & 0.26 & 0.25 & $\ldots$ & 0.23 & 0.25 & 0.25 \\
\hline A6 & 0.24 & 0.26 & $\ldots$ & 0.29 & 0.27 & 0.29 \\
\hline A7 & 0.27 & 0.26 & $\ldots$ & 0.23 & 0.25 & 0.25 \\
\hline A8 & 0.23 & 0.25 & $\ldots$ & 0.22 & 0.25 & 0.25 \\
\hline A9 & 0.24 & 0.22 & $\ldots$ & 0.21 & 0.25 & 0.26 \\
\hline A10 & 0.25 & 0.22 & $\ldots$ & 0.22 & 0.25 & 0.28 \\
\hline A11 & 0.26 & 0.23 & $\ldots$ & 0.25 & 0.26 & 0.22 \\
\hline A12 & 0.26 & 0.26 & $\ldots$ & 0.26 & 0.26 & 0.26 \\
\hline A13 & 0.26 & 0.26 & $\ldots$ & 0.26 & 0.26 & 0.26 \\
\hline A14 & 0.24 & 0.26 & $\ldots$ & 0.30 & 0.25 & 0.25 \\
\hline A15 & 0.25 & 0.22 & $\ldots$ & 0.27 & 0.22 & 0.26 \\
\hline A16 & 0.26 & 0.26 & $\ldots$ & 0.27 & 0.24 & 0.27 \\
\hline
\end{tabular}

Kemudian dilakukan perhitungan nilai bobot dikali normalisasi matriks untuk menentukan nilai terbaik pada masing-masing alternatif menggunakan persamaan 3 .

$$
\begin{aligned}
\text { Alternatif A1 : } \mathrm{C} 1=0,26 \times 15 & =0,26 \\
\mathrm{C} 2 & =0,26 \times 15=0,26 \\
\mathrm{C} 3 & =0,26 \times 15=0,26 \\
\mathrm{C} 4 & =0,27 \times 10=0,27 \\
\mathrm{C} 5 & =0,29 \times 15=0,29 \\
\mathrm{C} 6 & =0,28 \times 15=0,28 \\
\mathrm{C} 7 & =0,26 \times 15=0,26 \\
\mathrm{C} 8 & =0,27 \times 10=0,27 \\
\mathrm{C} 9 & =0,23 \times 10=0,23
\end{aligned}
$$

Hasil perhitungan dengan menggunakan persamaan 3 dapat dilihat pada Tabel 5, yaitu perkalian nilai bobot dan normalisasi matriks.

Tabel 5. Perkalian nilai bobot dan normalisasi matriks

\begin{tabular}{|c|c|c|c|c|c|c|}
\hline Alternatif & C1 & C2 & $\ldots$ & C7 & C8 & C9 \\
\hline A1 & 3.828 & 3.897 & $\ldots$ & 3.974 & 2.709 & 2.282 \\
\hline A2 & 3.517 & 3.865 & $\ldots$ & 3.403 & 2.478 & 2.161 \\
\hline A3 & 3.714 & 3.881 & $\ldots$ & 3.403 & 2.248 & 2.342 \\
\hline A4 & 3.468 & 3.865 & $\ldots$ & 3.679 & 2.478 & 2.222 \\
\hline A5 & 3.910 & 3.769 & $\ldots$ & 3.403 & 2.478 & 2.462 \\
\hline A6 & 3.632 & 3.897 & $\ldots$ & 4.360 & 2.651 & 2.882 \\
\hline A7 & 4.025 & 3.881 & $\ldots$ & 3.495 & 2.490 & 2.522 \\
\hline A8 & 3.517 & 3.785 & $\ldots$ & 3.311 & 2.478 & 2.462 \\
\hline A9 & 3.599 & 3.368 & $\ldots$ & 3.201 & 2.478 & 2.582 \\
\hline A10 & 3.812 & 3.368 & $\ldots$ & 3.348 & 2.536 & 2.822 \\
\hline A11 & 3.877 & 3.448 & $\ldots$ & 3.753 & 2.593 & 2.222 \\
\hline A12 & 3.894 & 3.865 & $\ldots$ & 3.863 & 2.593 & 2.582 \\
\hline A13 & 3.845 & 3.849 & $\ldots$ & 3.974 & 2.593 & 2.582 \\
\hline A14 & 3.599 & 3.881 & $\ldots$ & 4.489 & 2.536 & 2.462 \\
\hline A15 & 3.812 & 3.352 & $\ldots$ & 3.992 & 2.248 & 2.582 \\
\hline A16 & 3.894 & 3.929 & $\ldots$ & 4.047 & 2.363 & 2.702 \\
\hline
\end{tabular}

Untuk memperoleh alternatif terbaik berdasarkan masing-masing kriteria, kemudian dilakukan perhitungan dengan menjumlahkan semua kriteria pada alternatif dan dikurangi dengan nilai kriteria akhir. Dimana nilai yang benefit pada kriteria akan dijumlahkan, sedangkan nilai cost akan dikurangkan.

$$
\begin{gathered}
\text { Alternatif } \mathrm{A} 1:((\mathrm{C} 1+\mathrm{C} 2+\mathrm{C} 3+\mathrm{C} 4+\mathrm{C} 5+\mathrm{C} 6+\mathrm{C} 7 \\
+\mathrm{C} 8)-\mathrm{C} 9)
\end{gathered}
$$




$$
\begin{aligned}
: & ((3,83+3,90+3,85+2,74+4,40+ \\
& 4,20+3,97+2,71)-2,28) \\
: & 27,310
\end{aligned}
$$

Sehingga perolehan nilai alternatif berdasarkan kriteria, terdapat pada Tabel 6 .

Tabel 6. Hasil evaluasi nilai maksimal dan minimal

\begin{tabular}{|c|c|c|}
\hline Alternatif & Nomor Induk Siswa & Nilai Akhir \\
\hline A1 & 14.50 .107 & 27,310 \\
\hline A2 & 14.51 .071 & 24,686 \\
\hline A3 & 15.50 .193 & 24,871 \\
\hline A4 & 15.51 .057 & 24,825 \\
\hline A5 & 15.51 .063 & 25,068 \\
\hline A6 & 15.51 .066 & 27,416 \\
\hline A7 & 16.30 .001 & 25,761 \\
\hline A8 & 16.50 .018 & 23,271 \\
\hline A9 & 16.50 .041 & 22,666 \\
\hline A10 & 16.50 .056 & 22,635 \\
\hline A11 & 16.50 .063 & 24,963 \\
\hline A12 & 16.50 .066 & 25,770 \\
\hline A13 & 16.50 .068 & 24,635 \\
\hline A14 & 16.50 .077 & 25,375 \\
\hline A15 & 16.50 .081 & 24,953 \\
\hline A16 & 16.50 .090 & 24,400 \\
\hline
\end{tabular}

Dari hasil perhitungan menggunakan metode moora diatas, terdapat nilai kriteria antara $22 \mathrm{~s} / \mathrm{d} 27$, dengan nilai tertinggi diambil antara nilai 25 s/d 27 yang merupakan penerima beasiswa dari Dinas Sosial. Sehingga data penerima berdasarkan ranking nilai tertinggi dari perhitungan MOORA terdapat pada Tabel 7.

Tabel 7. Ranking Penerima Beasiswa

\begin{tabular}{|c|c|c|}
\hline Alternatif & Nomor Induk Siswa & Nilai Akhir \\
\hline A6 & 15.51 .066 & 27,416 \\
\hline A1 & 14.50 .107 & 27,310 \\
\hline A12 & 16.50 .066 & 25,770 \\
\hline A7 & 16.30 .001 & 25,761 \\
\hline A14 & 16.50 .077 & 25,375 \\
\hline A5 & 15.51 .063 & 25,068 \\
\hline
\end{tabular}

Dari 16 data alternatif yang digunakan, dan dihitung menggunakan metode MOORA maka diperoleh 6 data yang memiliki nilai tertinggi sebagai keputusan penerima beasiswa.

\section{ANALISA DAN DESAIN SISTEM}

Pada analisa dan desain sistem akan dilakukan pembahasan mengenai bagan alir program yang digunakan dalam perhitungan metode MOORA untuk memperoleh data penerima beasiswa tidak mampu pada Dinas Sosial. Berikut adalah flowchart perhitungan metode MOORA terdapat pada Gambar 1.

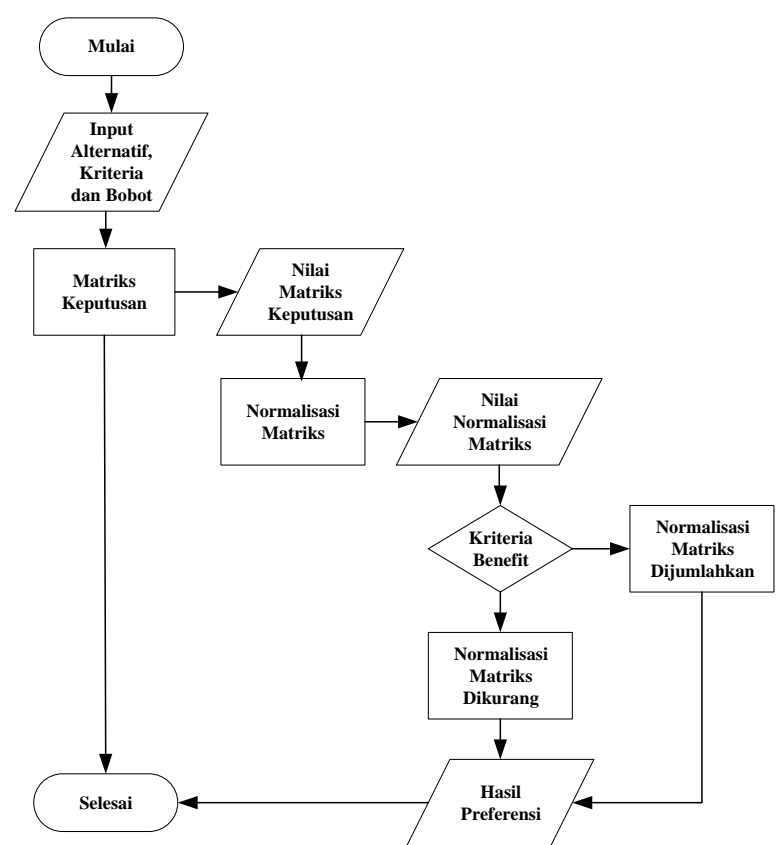

Gambar 1. Proses Perhitungan Metode MOORA

Berdasarkan gambar flowchart diatas, maka proses perhitungan dimulai pada input data alternatif, kriteria dan bobot penilaian, kemudian nilai matriks keputusan dihitung dan akan dilakukan normalisasi matriks. Nilai normalisasi matriks selanjutnya dilakukan proses penentuan kriteria benefit atau bukan, jika iya maka akan dijumlahkan, jika tidak nilai matriks akan dikurangi sehingga pada akhirnya akan menghasilkan nilai preferensi yang akan menentukan nilai hasil penerima beasiswa. Lebih jelasnya akan ditampilkan pada Gambar 2 program berikut.

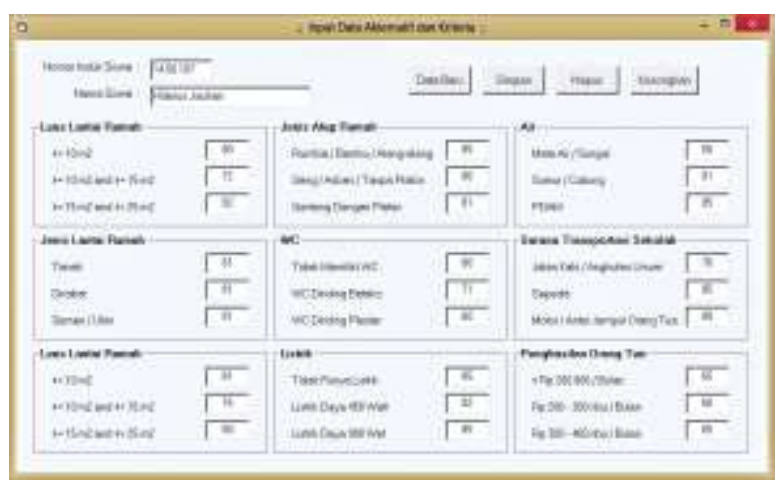

Gambar 2. Form menu input alternatif dan kriteria

Data alternatif dan kriteria yang telah dihitung kemudian disimpan ke dalam tabel untuk digunakan pada form perhitungan Metode MOORA terdapat pada Gambar 3. 


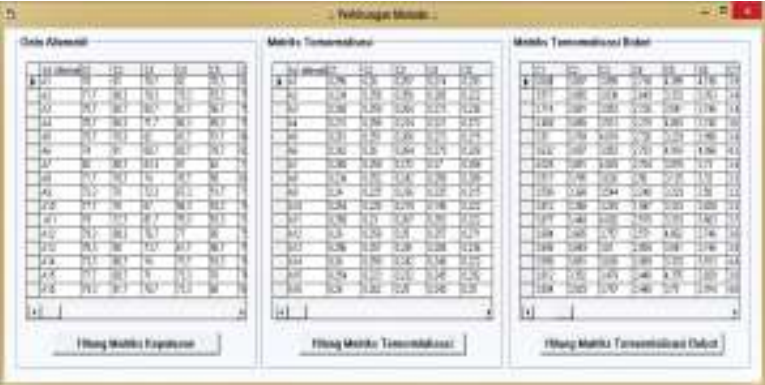

Gambar 3. Perhitungan Metode Moora

Perhitungan Moora untuk perhitungan matriks keputusan sampai pada matriks ternormalisasi bobot. Kemudian dari hasil perhitungan diperoleh nilai akhir yang dapat menentukan penerima beasiswa tidak mampu terdapat pada Gambar 4.

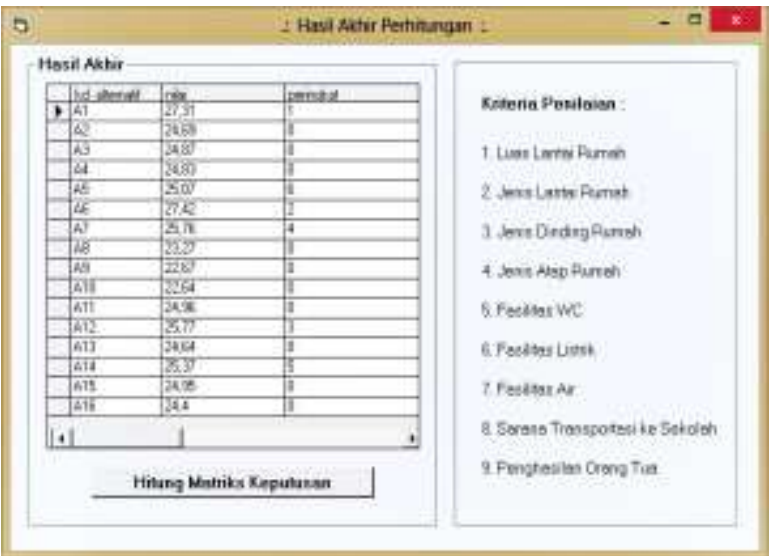

Gambar 4. Hasil Akhir Perhitungan

Berdasarkan hasil perhitungan, maka diperoleh 6 data sebagai penerima beasiswa dengan range nilai antara $25 \mathrm{~s} / \mathrm{d} 27$.

\section{KESIMPULAN}

Berdasarkan penelitian serta pengujian yang dilakukan, terdapat beberapa kesimpulan yaitu :

1. Metode Moora dapat digunakan sebagai alat pengambilan keputusan dalam menentukan data pemilihan peneriman beasiswa tidak mampu. Dalam pemilihan penerima beasiswa, kriteria yang digunakan hanya berupa fasilitas yang dimiliki siswa, namun tidak mencakup prestasi siswa di sekolah.

2. Penentuan hasil perhitungan dipengaruhi oleh kriteria-kriteria yang digunakan dalam penilaian sehingga semakin baik kriteria yang digunakan, hasilnya semakin akurat.

3. Hasil penelitian menggunakan metode MOORA, diperoleh jumlah siswa penerima beasiswa sebanyak 6 (enam) orang berdasarkan nilai tertinggi dengan range nilai antara 25 s/d 27.

\section{DAFTAR PUSTAKA}

[1] S. Rokhman, I. F. Rozi, and R. A. Asmara, "Pengembangan Sistem Penunjang Keputusan Penentuan UKT Mahasiswa Dengan Menggunakan Metode MOORA Studi Kasus Politeknik Negeri Malang," J. Inform. Polinema, vol. 3, pp. 36-42, 2017.

[2] Kusrini, "Sistem Pendukung Keputusan dan Aplikasinya," Andi, Yogyakarta, Indonesia, 2007, pp. 15-16.

[3] Gadakh Vijay. "Application of MOORA method for parametric optimization of milling process". International Jpurnal Of Applied Engineering Research. Din2011.

[4] Mesran, R. K. Hondro, M. Syahrizal, A. P. U. Siahaan, R. Rahim, and Suginam, "Student Admission Assessment using Multi-Objective Optimizaion on the Basis of Ratio Analysis (MOORA), "J. Online Jar. COT POLIPT, 2017, Vol 10, No. 7, pp. 1-6.

[5] S. Kusumadewi , S. Hartati, A. Harjoko, and R. Wardoyo, Fuzzy Multi-Attribute decision Making (Fuzzy MADM), Graha Ilmu, 2006, Yogyakarta, Indonesia, pp. 11-15.

[6] Supardi Yuniar Ir. Semua Bisa Menjadi Programmer VB 6 Hingga VB 2008 - Basic. PT. Elex Media Komputindo, 2011, Jakarta, Indonesia, pp. 30-40.

[7] Gadakh Vijay, Point of Sales Dengan Proteksi Setoran Kasir dan Stok Menggunakan VB 6, PT. Elex Media Komputindo, 2013, Jakarta, Indonesia, pp. 25-35.

[8] Khoirun Nisa, "Metode Moora Dan Waspas Untuk Pengambilan Keputusan Penentuan Prioritas Dalam Peningkatan Kualitas Mata Pelajaran". Jurnal Teknologi Informasi (JurTi). 2020. Volume 4, No. 1.

[9] S. Dian Utami Sutiksno, P. Rufaidah, H. Ali, and W. Souisa, "A Literature Review of Strategic Marketing and the Resource Based View of the Firm, 2007, "Int. J. Econ. Res., Vol. 14, No. 8, pp. 59-73.

[10] Mesran, R. K. Hondro, M. Syahrizal, A. P. U. Siahaan, R. Rahim, and Suginam, "Sistem Pendukung Keputusan Pemilihan Peserta Jaminan Kesehatan Masyarakat (Jamkesmas) Menerapkan Metode MOORA, "Media Informatikan Budidarma, 2018, Vol 2, No. 2, pp. 16-22.

[11] Manurung Samuel, "Sistem Pendukung Keputusan Pemilihan Guru dan Pegawai Terbaik Menggunakan Metode MOORA, "Jurnal Simetris", 2018, Vol 9, No. 1.

[12] Mandal, U. K. And Sarkar, B. Selection of Best Intelligent Manufacturing System (IMS) Under Fuzzy Moora Conflicting MCDM Environment. "International Journal of Emerging Technology and Advance 
Engineering (IJETAE), 2012, Vol 2, Issue 9. Pp. 301-310.

[13] Attri, R., and Grover, S. 2013. Decision Making Over the Production System Life Cycle: MOORA method. Int J Syst Assure eng Manag, 2014, Vol 5.

[14] Suprianto, Fadlil A. And Sunardi. Aplikasi Sistem Temu Kembali Angket Mahasiswa Menggunakan Metode Generalized Vector Space Model. Jurnal Teknologi Informasi dan Ilmu Komputer, 2019, Vol 6. 